Journal of Agriculture and Natural Resources (2020) 3(1): 61-68

ISSN: 2661-6270 (Print), ISSN: 2661-6289 (Online)

DOI: https://doi.org/10.3126/janr.v3i1.27025

Research Article

\title{
Farmers' perception on the performance of different rice varieties in Kapilvastu district, Nepal
}

\author{
Sundar Sapkota ${ }^{1 *}$ and Sanjib Sapkota ${ }^{2}$ \\ ${ }^{1}$ Department of Biology, Eastern New Mexico University, Portales, NM 88130, USA. \\ ${ }^{2}$ Department of Biological Sciences, Simon Fraser University, Burnaby, V5A 1S6, Canada. \\ *Correspondence: sundar.sapkota@enmu.edu \\ ORCID: https://orcid.org/0000-0001-5948-9523
}

Received: August 21, 2019; Accepted: November 15, 2019; Published: January 7, 2020

(C) Copyright: Sapkota and Sapkota (2020).

(c) (1) (3)

This work is licensed under a Creative Commons Attribution-Non Commercial 4.0 International License.

\begin{abstract}
Rice is the major staple food crop in Nepal. To date, several rice varieties have been developed and released in Nepal. However, rice production is far below in comparison with its production potential. A household survey was conducted in Bangaganga municipality of Kapilvastu district in 2018 to assess farmers' perception on performance of four different rice varieties (Radha-4, Ramdhan, Gorakhnath, and Sawa). The data were collected from a total of 120 rice farmers (randomly selected) using the interview schedule and analyzed using descriptive statistics, Likert scale, and indexing technique. Statistical analysis showed that the Ramdhan variety had the highest yield (4.95 t/ha), whereas Radha-4 had the lowest yield (3.15 t/ha). The most disease and drought-tolerant variety, as perceived by the farmers, was Radha-4. Smut and Khaira were perceived as the primary diseases whereas Brown planthopper and Rice Gundhi bug were the most important insects of all studied rice varieties. The study recommended that the plant breeders should focus on developing site-specific rice varieties to meet the multiple concerns of the farmers, such as higher yield and stress-tolerant. The farmers should be made aware of varietal selection and crop pest management techniques via training programs, which further helps to reduce the yield gap between farmers' field and research field.
\end{abstract}

Keywords: Oryza sativa, perception, varieties, indexing, farmer

Correct citation: Sapkota, S., \& Sapkota, S. (2020). Farmers' perception on the performance of different rice varieties in Kapilvastu district, Nepal. Journal of Agriculture and Natural Resources, 3(1), 61-68. DOI: https://doi.org/10.3126/janr.v3i1.27025 
Journal of Agriculture and Natural Resources (2020) 3(1): 61-68

ISSN: 2661-6270 (Print), ISSN: 2661-6289 (Online)

DOI: https://doi.org/10.3126/janr.v3i1.27025

\section{INTRODUCTION}

Rice (Oryza sativa L., Poaceae family) is the primary food crop to more than half of the world's population. It provides diet to millions of Asians, Africans, and Latin Americans in tropics and subtropics regions (Yoshida, 1981). In Nepal, rice ranks first food crop, provides more than 50\% calories to the Nepalese diet (Basnet, 2008; Gauchan et al., 2014; Kharel et al., 2018: Gadal et al., 2019; Devkota et al., 2019). Rice contributed $31.4 \%$ and $21 \%$ to GDP and AGDP respectively (MoF, 2017; Bhusal et al., 2018). Rice can be grown in diverse elevations ranging from 50 to 3,000 meters. Modern rice varieties were developed and released in Nepal since 1960s. Kapilvastu district, because of its climate and environment, reported as one of the major rice-producing regions of Nepal. Most rice farmers in Kapilvastu district grow a few popular varieties such as Sawa, Ramdhan, Radha-4, and Gorakhnath. In addition, other cultivars such as Golden Mansuli, Loknath, Hybrid (6444), Hardinath, Sukha3, Sabitri, Kala namak, Mayur, Motisabha, Mahima, Sindhur, Sawa Saba-1, and Swarna Sawa-1 were grown in the district (DADO, 2016; Sapkota \& Sapkota, 2019).

It is essential to understand what farmers know about plant varieties, their perceptions about the crop yield, stress incidence, and yield loss. Farmers' pest and disease perception and damage quantification might be quite different and less accurate than biological research in the field. However, farmers' knowledge provides crucial information as farmers decide on a course of action based on what they think the problem is, not on the actual problem. If farmers have better knowledge about plant varieties, pest's infestation, and drought effect, yield loss could be reduced substantially (Adam et al., 2015).

Farmers benefits from cultivating a specific crop variety. The decision to grow particular crop variety is determined by the household's perception of its ability to fulfill the household's requirement and relative to other alternative options (Brush and Meng, 1998). Improved rice varieties can change in farmer's status. Changes are associated with selection and seed management practices, which are, in turn, affected by economic, social, and cultural conditions. Farmer's understanding of diseases is reported for millet in Ghana, (Tanzubil \& Yankubu, 1997), cotton in Africa (Ochou et al., 1998), and vegetables in Botswana (Obopile et al., 2008). Furthermore, Rubia et al. (1996) reported farmers' perception of white stem borer of rice in Indonesia. However, in Nepal, farmers' perception on crop performance has not been reported yet. Building knowledge among farmers is, therefore, a meaningful way to enhance crop production. Thus, this study aims to assess farmers' perception on the performance of four different rice varieties in Banganga municipality of Kapilvastu district.

\section{METHODOLOGY}

\section{Study area}

A survey study was conducted in Banganga municipality (latitude: $27^{\circ} 35^{\prime \prime}-27^{\circ} 48^{\prime \prime} \mathrm{N}$; longitude: $83^{\circ} 03^{\prime \prime} \mathrm{E}$; altitude: $107 \mathrm{~m}$ ) of Kapilvastu district in 2018 . The area was selected purposively as it was noted for extensive rice production according to the rice implementation zone, Kapilvastu. The average annual minimum, maximum temperature, and precipitation of the study site were $6^{\circ} \mathrm{C}, 38^{\circ} \mathrm{C}$, and $130 \mathrm{~cm}$, respectively. 
Journal of Agriculture and Natural Resources (2020) 3(1): 61-68

ISSN: 2661-6270 (Print), ISSN: 2661-6289 (Online)

DOI: https://doi.org/10.3126/janr.v3i1.27025

\section{Selection of farmers}

Rice farmers were selected based on the criteria that they had planted different varieties of rice. The total sampling population was five hundred rice farmers and was obtained from the rice implementation zone, Kapilvastu. One hundred twenty rice farmers (30 farmers for each four varieties: Gorakhnath, Radha-4, Ramdhan, and Sawa) were randomly chosen for the study.

\section{Data collection and analysis}

Data were collected from rice farmers using an interview schedule. The collected data were processed into Microsoft Excel. The yield of different rice varieties was analyzed using descriptive statistical tool such as mean. The importance and severity of biotic and abiotic stress were ranked to highlight farmers' perceptions. Likert scale and indexing technique were used to quantify farmer perception on different variables. The average of the index was determined, and values were compared to give an overall ranking for the variety. Following formula was used to determine the index of importance (Miah, 1993).

$$
\operatorname{Iimp}=\mathrm{I}=\sum \frac{s_{\mathrm{i}} f_{i}}{N}
$$

Where,

Iimp = Index of importance

$\mathrm{Si}=$ Scale value

$\mathrm{fi}=$ frequency of importance given by the respondents

$\mathrm{N}=$ Total number of respondents

Different scale values such as $1,(1-1 / n),(1-2 / n),(1-3 / n) \ldots$ were used, where $n$ denotes number of categories in ranking.

Subedi et al. (2019a) used this formula to identify the constraints associated with the potato production in Terai region of Nepal. This formula was applied by Shrestha and Shrestha (2017) to rank the problems associated with maize seed production. Subedi et al. (2019b) used this technique to explore the problems associated with wheat production.

\section{RESULTS AND DISCUSSION}

\section{Rice yield}

The greatest grain yield was produced from Ramdhan variety followed by Gorakhnath (Table 1). The final rice production depends on genetic makeup, crop adaptability to the environment, stress incidence, and cultivation practices. The higher yield of Ramdhan could, in part, be due to the presence of a better gene that can resist disease and weeds infestation. Chendge et al. (2017) reported that the genetic makeup of the crop is the primary factor determining its growth and production. The production potential of rice varieties: Radha-4, Ramdhan, and Sawa at the national level in Nepal are 3.2 t/ha, 4-7.2 t/ha, and 3.5- $4 \mathrm{t} / \mathrm{ha}$, respectively (AICC, 2018). Efisue et al. (2008) reported that the significant yield gap between farmers' yield and the yield potential is probably due to: a) drought stress b) use of lowyielding varieties and c) lack of agricultural inputs such as fertilizers. Thus, emphasizes should be given in developing new varieties that are drought-tolerant, high yielding, and adaptable to environments. 
Journal of Agriculture and Natural Resources (2020) 3(1): 61-68

ISSN: 2661-6270 (Print), ISSN: 2661-6289 (Online)

DOI: https://doi.org/10.3126/janr.v3i1.27025

Table 1. Average yield of four different rice varieties perceived by the farmers' in Banganga, Kapilvastu

\begin{tabular}{lc}
\hline Rice Varieties & Grain Yield (t/ha) \\
\hline Ramdhan & 4.95 \\
Radha-4 & 3.15 \\
Gorakhnath & 4.2 \\
Sawa & 3.75 \\
\hline
\end{tabular}

Source: Field survey, 2018

Rice varieties and disease incidence

Farmers perceived Khaira as the most critical disease for Radha- 4 and Ramdhan rice. In contrast, Smut ranks as the primary disease for Gorakhnath and Sawa varieties (Table 2). This finding corresponds to the reports of Khanal et al. (2017), who stated that Radha-4 was resistant against blast disease.

Table 2. Farmers' perception on disease incidence for different rice varieties in Banganga, Kapilvastu

\begin{tabular}{lllllllll}
\hline \multirow{2}{*}{$\begin{array}{l}\text { Varieties/ } \\
\text { Diseases }\end{array}$} & \multicolumn{2}{c}{ Radha-4 } & \multicolumn{2}{c}{ Ramdhan } & \multicolumn{2}{c}{ Sawa } & \multicolumn{2}{c}{ Gorakhnath } \\
\cline { 2 - 9 } Smdex & Rank & Index & Rank & Index & Rank & Index & Rank \\
Smut & 0.69 & II & 0.71 & III & 1 & I & 0.95 & I \\
Khaira & 0.51 & IV & 0.60 & IV & 0.51 & IV & 0.67 & III \\
Sheath Blight & 0.88 & I & 0.86 & I & 0.78 & II & 0.76 & II \\
Brown Spot & 0.52 & III & 0.43 & V & 0.43 & V & 0.56 & IV \\
Bacterial Blight & 0.31 & VI & 0.80 & II & 0.63 & III & 0.56 & IV \\
Foot Rot & 0.34 & V & 0.33 & VII & 0.34 & VII & 0.35 & VI \\
\hline & 0.22 & VII & 0.34 & VI & 0.40 & VI & 0.21 & VII \\
\hline
\end{tabular}

Rice varieties and insect incidence

Notably, farmers were able to differentiate various insects and their intensity in the rice field. Three rice varieties: Radha-4, Sawa, and Gorakhnath, were infected by one remarkable insect, Brown planthopper. For Ramdhan rice, farmers perceived Rice Gundhi Bug as the major insect (Table 3).

Table 3. Farmers' perception on insect incidence for different rice varieties in Banganga, Kapilvastu

\begin{tabular}{llllllllll}
\hline Varieties/ & \multicolumn{2}{l}{ Radha-4 } & \multicolumn{3}{c}{ Ramdhan } & \multicolumn{2}{c}{ Sawa } & \multicolumn{2}{c}{ Gorakhnath } \\
\cline { 2 - 9 } Insects & Index & Rank & Index & Rank & Index & Rank & Index & Rank \\
\hline Grasshopper & 0.58 & III & 0.58 & IV & 0.42 & IV & 0.54 & IV \\
Rice Gundhi bug & 0.79 & II & 0.83 & I & 0.86 & II & 0.79 & II \\
Leaf Roller & 0.38 & VI & 0.48 & V & 0.35 & VI & 0.37 & VI \\
Brown planthopper & 0.89 & I & 0.75 & II & 0.90 & I & 0.80 & I \\
Armyworm & 0.54 & IV & 0.64 & III & 0.69 & III & 0.76 & III \\
Stem borer & 0.42 & V & 0.37 & VI & 0.36 & V & 0.40 & V \\
\hline
\end{tabular}

Source: Field survey, 2018

\section{Rice varieties and weed incidence}

Farmers were asked to prioritize different weeds that they observed the most in their rice field. Farmers reported Echinochloa as the major weed in Sawa and Gorakhnath rice, whereas Cynodon as the least growing weed for those rice varieties (Table 4). Dry tillage, alternate wetting and drying practices favor germination and growth of highly competitive 
Journal of Agriculture and Natural Resources (2020) 3(1): 61-68

ISSN: 2661-6270 (Print), ISSN: 2661-6289 (Online)

DOI: https://doi.org/10.3126/janr.v3i1.27025

weeds, causing yield loss of $50-91 \%$ (Elliot et al., 1984). Thus, timely weed control is vital to enhance rice production.

Table 4. Farmers' perception on weed infestation for different rice varieties in Banganga, Kapilvastu

\begin{tabular}{llclcccccc}
\hline \multirow{2}{*}{$\begin{array}{l}\text { Varieties/ } \\
\text { Weeds }\end{array}$} & \multicolumn{3}{c}{ Radha-4 } & Ramdhan & \multicolumn{2}{c}{ Sawa } & \multicolumn{2}{c}{ Gorakhnath } \\
\cline { 2 - 9 } Cynodon & Index & Rank & Index & Rank & Index & Rank & Index & Rank \\
Echinocloa & 0.75 & I & 0.73 & I & 0.38 & IV & 0.44 & IV \\
Digitaria & 0.55 & IV & 0.59 & II & 0.94 & I & 0.961 & I \\
Fimbrysylis & 0.71 & II & 0.47 & IV & 0.67 & III & 0.59 & III \\
\hline
\end{tabular}

Source: Field survey, 2018

\section{Overall ranking of biotic stress incidence in different rice varieties}

The overall biotic stress was determined based on the index of priority value, which was calculated taking the average of individual stress incidence rank. The highest disease incidence was found in Sawa rice, followed by Ramdhan and Gorakhnath. Similarly, farmers perceived the most top insect and weed incidence in Gorakhnath and Radha-4 rice respectively (Table 5).

Table 5. Farmers' perception on incidence of biotic stress for different rice varieties in Banganga, Kapilvastu

\begin{tabular}{lccccccccc}
\hline Biotic stress/ & \multicolumn{3}{c}{ Disease incidence } & \multicolumn{3}{c}{ Insect incidence } & \multicolumn{3}{c}{ Weed incidence } \\
\cline { 2 - 10 } Varieties & Weightage & Index & Rank & Weightage & Index & Rank & Weightage & Index & Rank \\
\hline Gorakhnath & 17.4 & 0.58 & II & 18.34 & 0.61 & I & 18 & 0.60 & III \\
Radha-4 & 14.854 & 0.50 & III & 18 & 0.60 & III & 18.52 & 0.62 & I \\
Ramdhan & 17.4 & 0.58 & II & 18.26 & 0.608 & II & 18.25 & 0.61 & II \\
Sawa & 17.56 & 0.59 & I & 17.92 & 0.59 & IV & 17.96 & 0.59 & IV \\
\hline
\end{tabular}

Source: Field survey, 2018

\section{Performance of rice varieties in drought condition}

According to the Likert scale, farmers were asked to indicate the performance of rice varieties under drought condition on a different scale; -1 (drought susceptible or poor performance), 0 (slight drought resistant or average performance), 1 (drought resistant or good performance). Farmers in Banganga mentioned Radha-4 as the most drought-tolerant variety followed by Ramdhan. In contrast, farmers perceived Sawa as the most drought susceptible variety (Table 6). Efisue et al. (2008) reported drought stress hampers both vegetative and reproductive stages of rice. The genotypic variation existing among rice varieties cause the plant to respond differently under drought condition. Drought at the vegetative stage: a) delays flowering time b) reduces tiller numbers and c) lowers biomass (Lilley and Fukai, 1994). Furthermore, Villegas et al. (2007) reported that spike length and weight were negatively associated with the drought susceptibility index. 
Journal of Agriculture and Natural Resources (2020) 3(1): 61-68

ISSN: 2661-6270 (Print), ISSN: 2661-6289 (Online)

DOI: https://doi.org/10.3126/janr.v3i1.27025

Table 6. Farmers' perception on performance of rice varieties in drought condition in Banganga, Kapilvastu

\begin{tabular}{lcccccc}
\hline \multirow{2}{*}{ Varieties } & Scales & & & \\
\cline { 2 - 7 } & Good (1) & Average $(0)$ & Poor $(-1)$ & Weightage & Index & Rank \\
\hline Gorakhnath & 0 & 16 & 14 & -14 & -0.47 & III \\
Radha-4 & 30 & 0 & 0 & 30 & 1 & I \\
Ramdhan & 10 & 17 & 3 & 7 & 0.23 & II \\
Sawa & 0 & 8 & 22 & -22 & -0.73 & IV \\
\hline
\end{tabular}

Source: Field survey, 2018

\section{Yield loss due to biotic stress}

Farmers were asked to indicate grain yield loss due to biotic stress for four rice varieties on different scales: -1 (negligible), 0 (slight), and 1 (severe). The scale values were further used to determine index value and provide the final rank. Farmers perceived a severe yield loss in Radha- 4 variety, followed by Gorakhnath and Sawa due to disease. Farmers mentioned insects as the primary cause for yield reduction in Gorakhnath rice, and second biotic cause to Radha-4 and Sawa. Farmers ranked weed as the major biotic stress responsible for the significant yield reduction in Ramdhan rice (Table 7). Additionally, the net benefit obtained from rice cultivation depends on production cost and market price. Sapkota and Sapkota, (2019) reported that Sawa variety had highest benefit cost ratio in Banganga municipality of Kapilvastu district in Nepal.

Table 7. Farmers' perception on yield loss due to biotic stress for different rice varieties in Banganga, Kapilvastu

\begin{tabular}{lccccccccc}
\hline Biotic stress/ & \multicolumn{3}{c}{ Disease } & \multicolumn{3}{c}{ Insect } & \multicolumn{3}{c}{ Weed } \\
\cline { 2 - 10 } Varieties & Weightage & Index & Rank & Weightage & Index & Rank & Weightage & Index & Rank \\
\hline Gorakhnath & -4 & -0.13 & II & 4 & 0.13 & I & 4 & -0.13 & III \\
Radha-4 & 2 & 0.06 & I & -1 & -0.03 & II & -1 & -0.03 & II \\
Ramdhan & -6 & -0.2 & IV & -5 & -0.17 & III & 4 & 0.13 & I \\
Sawa & -5 & 0.16 & III & -1 & -0.03 & II & -9 & -0.30 & IV \\
\hline & & & & & & & Source: Field survey, 2018
\end{tabular}

\section{CONCLUSION}

In summary, the farmers in the Banganga municipality cultivated different varieties of rice. The farmers in the study area had a good understanding of crop production, stress incidence, and damaged yield and were concerned about crop performance. It is essential to incorporate farmers' opinion about the crop performance in breeding programs to encourage farmers for the adoption of right varieties which in turn enhance crop yield and quality. Furthermore, crop improvement programs should emphasize the development of ecologies specific crop varieties to increase impact. The farmers should be made aware of varietal selection and crop pest management techniques via training programs, which further helps to reduce the yield gap between farmers' field and research field.

\section{ACKNOWLEDGEMENTS}

The authors are grateful to Professor Dr. Indira Bhattarai and Rice Implementation Zone, Kapilvastu, Nepal, for their technical support during the research period. 
Journal of Agriculture and Natural Resources (2020) 3(1): 61-68

ISSN: 2661-6270 (Print), ISSN: 2661-6289 (Online)

DOI: https://doi.org/10.3126/janr.v3i1.27025

Author contributions

Conceptualization, S.S. (Sundar Sapkota) and S.S. (Sanjib Sapkota); Methodology, S.S. (Sundar Sapkota), data collection and analysis, S.S. (Sundar Sapkota); original draft, S.S. (Sundar Sapkota); Writing- review and editing, S.S. (Sundar Sapkota) and S.S. (Sanjib Sapkota).

\section{Conflict of interest}

Authors declare no conflict of interest.

\section{REFERENCES}

Adam, R. I., Sindi, K., \& Badstue, L. (2015). Farmers' knowledge, perceptions and management of diseases affecting sweet potatoes in the Lake Victoria Zone region, Tanzania. Crop Protection, 72, 97-107.

AICC. (2018). Krishi Diary. (2018). Agriculture Information and Communication Centre. Lalitpur, Nepal

Basnet, B.M.S. (2008). Environment friendly technologies for increasing rice productivity. The Journal of Agriculture and Environment, 9: 34-40.

Bhusal, N.R., Acharya, B., Devkota, A.R., \& Shrestha, J. (2018). Field evaluation of Trichoderma viride for the management of rice leaf blast disease in Pyuthan district, Nepal. Journal of the Institute of Agriculture and Animal Science, 35, 259-266.

Brush, S. B., \& Meng, E. (1998). Farmers' valuation and conservation of crop genetic resources. Genetic Resources and Crop Evolution, 45(2), 139-150.

Chendge, P. D., Chavan, S. A., Patil, A., \& Kumar, S. (2017). Impact of sowing times and different varieties on yield potential and economics of rice in Konkan. Journal of Pharmacognosy and Phytochemistry, 6(5), 2467-2471.

DADO. (2016). Annual district profile. District Agriculture Development Office, Kapilvastu, Nepal.

Devkota, S., Panthi, S., \& Shrestha, J. (2019). Response of rice to different organic and inorganic nutrient sources at Parwanipur, Bara district of Nepal. Journal of Agriculture and Natural Resources, 2(1), 53-59.

Efisue, A., Tongoona, P., Derera, J., Langyintuo, A., Laing, M., \& Ubi, B. (2008). Farmers' perceptions on rice varieties in Sikasso region of Mali and their implications for rice breeding. Journal of Agronomy and Crop Science, 194(5), 393-400.

Elliot, P. C., Navarez, D. C., \& Estano, D. B. (1984). Determining suitable weed control practices for dry-seeded rice (Oryza sativa) in farmers' fields (Philippines). In International Rice Research Institute, Los Banos, Laguna (Philippines). Dept. of Agronomy. 15. Anniversary and Annual Convention Pest Control Council of the Philippines. Los Banos, Laguna (Philippines). 21-23.

Gadal, N., Shrestha, J., Poudel, M. N., \& Pokharel, B. (2019). A review on production status and growing environments of rice in Nepal and in the world. Archives of Agriculture and Environmental Science, 4(1), 83-87.

Gauchan, D., Sapkota, B., Gautam, S., Magar, D.T., Sharma, B., Amatya, S., Sapkota, S., Nepali, M.B., Singh, S. and Singh, U.S. (2014). Development and dissemination of stress-tolerant rice varieties in Nepal. Nepal Agricultural Research Council, Lalitpur, Nepal. 1-24. 
Journal of Agriculture and Natural Resources (2020) 3(1): 61-68

ISSN: 2661-6270 (Print), ISSN: 2661-6289 (Online)

DOI: https://doi.org/10.3126/janr.v3i1.27025

Khanal, M.P., Sapkota, D., \& Kharel, B. (2017). Varietal characteristics of important crop varieties developed in Nepal, Seed Quality Control Center, Lalitpur, Nepal.

Kharel, L., Ghimire, S. K., Shrestha, J., Kunwar, C. B., \& Sharma, S. (2018). Evaluation of rice genotypes for its response to added fertility levels and induced drought tolerance during reproductive phase. Journal of AgriSearch, 5(1), 13-18.

Lilley, J. M., \& Fukai, S. (1994). Effect of timing and severity of water deficit on four diverse rice cultivars III. Phenological development, crop growth and grain yield. Field Crops Research, 37(3), 225-234.

Miah, A.Q. (1993). Applied statistics: A course handbook for human settlements planning. Asian Institute of Technology, Division of Human Settlements Development, Bangkok, Thailand. 412.

MoF. (2017). Economic Survey. Singh Durbar, Kathmandu: Government of Nepal, Ministry of Finance.

Obopile, M., Munthali, D. C., \& Matilo, B. (2008). Farmers' knowledge, perceptions and management of vegetable pests and diseases in Botswana. Crop Protection, 27(8), $1220-1224$.

Ochou, G. O., Matthews, G. A., \& Mumford, J. D. (1998). Comparison of different strategies for cotton insect pest management in Africa. Crop Protection, 17(9), 735-741.

Rubia, E. G., Lazaro, A. A., Heong, K. L., \& Norton, G. A. (1996). Farmers' perceptions of the white stem borer Scirpophaga innotata (Walker), in Cilamaya, West Java, Indonesia. Crop Protection, 15(4), 327-333.

Sapkota, S., \& Sapkota, S. (2019). Benefit cost analysis of different rice varieties in Kapilvastu district, Nepal. International Journal of Applied Sciences and Biotechnology, 7(2), 222-226.

Shrestha, A., \& Shrestha, J. (2017). Production, problems and decision making aspects of Maize seed producers in Banke District, Nepal. Azarian Journal of Agriculture, 4(6), 212-216.

Subedi, S., Ghimire, Y.N., Adhikari, S.P., Devkota, D., Shrestha, J., Poudel, H.K., \& Sapkota, B.K. (2019b). Adoption of certain improved varieties of wheat (Triticum aestivum L.) in seven different provinces of Nepal. Archives of Agriculture and Environmental Science, 4(4), 404-409.

Subedi, S., Ghimire, Y.N., Gautam, S., Poudel, H.K., \& Shrestha, J. (2019a). Economics of potato (Solanum tuberosum L.) production in terai region of Nepal. Archives of Agriculture and Environmental Science, 4(1), 57-62.

Tanzubil, P. B., \& Yakubu, E. A. (1997). Insect pests of millet in Northern Ghana. 1. Farmers' perceptions and damage potential. International Journal of Pest Management, 43(2), 133-136.

Villegas, D., Garcia del Moral, L. F., Rharrabti, Y., Martos, V., \& Royo, C. (2007). Morphological traits above the flag leaf node as indicators of drought susceptibility index in durum wheat. Journal of Agronomy and Crop Science, 193(2), 103-116.

Yoshida, S. (1981). Fundamentals of rice crop science. International Rice Research Institute. Los Baños, Laguna, Philippines, 269. 